\title{
STOCKHOLDERS' AGREEMENTS IN THE CLOSELY HELD CORPORATION*
}

\author{
GEORGE D. HORNSTEIN†
}

IN the field of corporation law, attention has principally been focused on the large, publicly financed corporation. Most efforts have been directed toward protecting the investing public against the dangers inherent in the divorcement of ownership and control. Thus there has been extensive consideration of such problems as frauds in the promotion of the corporation, misappropriations by management during its operation, and non-disclosures to stockholders designed to stave off demands for a change in management.

Application of the term "corporation" is not limited, however, to the gigantic publicly held corporation with its hundreds of thousands of stockholders. The same name is also applied to the one-man corporation and to the small corporation with but few participants, although their problems are quite different from those of the large corporation. In the small corporation where the stockholders are often directors and officers, each member usually has a sense of personal responsibility which comes from handling his own funds. And whereas the average lawyer will have occasion to advise on a problem concerning a large corporation perhaps once or twice during his career, he will probably have repeated experience with small corporations.

The corporate form is generally employed by a small business because the venturers want limitation of liability and certain imagined tax advantages, precisely as does the single stockholder in the one-man corporation. But at the same time, when the stockholders are more than one, they generally prefer certain of the attributes of partnership, particularly with respect to control and dissolution. In effect, they want an "incorporated partnership."

The problem which these entrepreneurs and their legal advisors face is to reconcile these aims with the corporate norms which have been so often stated to be prerequisites of corporate existence. These norms-originally formulated to protect the investing stockholders in large corporations-include control of corporate activities by a board of directors, rule by majority vote, free transferability of ownership shares, and continuity of organizational life not terminated by the death or withdrawal of a participant. To what extent does the corporate form necessitate these corporate "norms"?

Some "corporations," more than one would fancy, omit the barest

* The following article is the substance of an address delivered at the Association of the Bar of the City of New York, under the auspices of the Committee on Post Admission Legal Education.

t Member of the New York Bar. 
minima of corporate norms. Having adopted the corporate form, some business men proceed to disregard it completely and to operate as a partnership. More often than not, the result is that eventually the participants find themselves "hooked" as individuals for a partnership liability which they thought had been avoided when their lavyer handed them a corporate seal.

Another sizeable group comprehends the necessity for strictly observing the corporate form, acting by corporate resolutions, keeping corporate books, maintaining a separate bank account for the corporation, and filing corporate tax returns. Yet, feeling that he is really a partner, each participant is willing to have his power to shape corporate policies or to sell his stock determined by preliminary informal "understandings." Such questions as the existence of the corporation after withdrawal (or possibly death) of one of the original venturers are given similar informal treatment. But too often it turns out that each party has a different version of the understanding. From this group, as a consequence, comes most of the bitter litigation involving closely held corporations.

Finally, there are two other groups which also strictly observe the corporate form. These groups reach an understanding as to deviations from corporate "norms" and then embody their agreement in written form, hoping thereby to avoid subsequent disputes. These agreements are the device most successfully employed in the closely held corporation to mitigate the restrictiveness of traditional corporation law.

The first of these groups, the "Clark-Dodge type," involves a minority stockholder who wants protection in the form of a "veto power" against conduct which he thinks may prejudice him. Sometimes he is a one-third stockholder in business with another who holds twothirds of the stock. Sometimes he is one of three individual venturers each owning a one-third interest, and each of whom is equally fearful that his two fellows may gang up on him. Of course, the precise percentage of stock held is immaterial.

The other group, the "Long Park type," involves one or several stockholders who want assurance that they will be able to control the enterprise either for a period of years or for the life of the corporation. They may own any amount of the stock. Yet regardless of how the stock ownership may vary at the time or in the future, they want control vested in themselves. And their fellow venturers are willing to grant it.

These last two groups are at opposite extremes. The one would give every stockholder an absolute veto power over all action. The other would prevent anyone but the original dominant participant from ever having any voice. Both groups fear control by an independent board of directors and fear a majority vote of stockholders which might change the make-up of the board. 


\section{Control BY Directors and Stockholders}

Whether management by the board of directors and ultimate control by the stockholders are norms which are essential to corporate existence-whether conformity to them is the price which must be paid for limited liability-are questions which courts have frequently been called upon to decide. Although the goal of most investors in closely held corporations is to get as close as possible to a partnership without losing the advantages of incorporation, most courts will not permit the parties to ignore these norms merely by their agreeing that the incorporated venture shall be operated as a partnership. ${ }^{1}$ Numerous dicta indicate, however, that if the stock certificates were issued to " $A$ and $B$, as partners," rather than to the parties severally, they would be partners inter se while still enjoying the protection of limited liability. ${ }^{2}$ In theșe jurisdictions an elaborate partnership agreement may be necessary to clarify the parties' rights. And if the practice becomes wide-spread the legislature may enact laws to limit it.

\section{Choice and Removal of Directors}

In the absence of corrective legislation most courts will hold invalid stockholders' agreements requiring that directors be elected by unanimous consent. In the Benintend $i^{3}$ case, the New York Court of Appeals invalidated a by-law calling for such unanimity. However, Section 9 of the New York Stock Corporation Law now authorizes such a requirement. ${ }^{4}$

Although a general requirement of unanimity might not be valid, an agreement signed by all stockholders to vote for certain specified persons as directors would probably be valid and enforceable every:where. In most states the agreement would be enforceable even if some stockholders had not signed. ${ }^{5}$ In New York, certainly, even without statute, a majority of the stockholders may assure the identity of the board of directors by committing themselves to vote for one another or for other specified persons as directors.

If stockholders make special provisions for the election of directors, they may also want to vary the normal procedure for removal. Direc-

1. If the stock certificates were issued severally, the parties cannot enforce an agreement that they will operate as a partnership. Jackson v. Hooper, 76 N.J. Eq. 592, 599, 75 Atl. 568, 571 (Ct. Err. \& App. 1910). Contra: Wabash Ry. v. American Refrigerator Transit Co., 7 F.2d 335 (8th Cir. 1925), cert. denied, 270 U.S. 643 (1926).

2. See Seitz v. Michel, 148 Minn. 80, 84, 181 N.W. 102, 104 (1921); King v. Barnes, 109 N.Y. $267,288,16$ N.E. 332,338 (1888).

3. Benintendi v. Kenton Hotel, Inc., 294 N.Y. 112, 60 N.E. 2d 829 (1945).

4. So also in Delaware, provided the provision is in the charter. DEL. REv. CODE $\S \S 2037$ (11), 2049 (1935).

5. In cases usually cited for the contrary it has been found on examination that the courts were influenced by what they felt was an attempt to control the directors. Sec, e.g., Creed v. Copps, 103 Vt. 164, 152 At1. 369 (1930). 
tors ordinarily may not be removed without cause. Hence any understanding to the contrary should be recorded in the stockholders' agreement and embodied in the certificate of incorporation or the by-laws.

\section{Appointment and Removal of Officers}

Parties to stockholders' agreements seek more frequently to control the power of the board of directors to appoint officers and managers than the power to curtail any other exercise of the board's prerogatives. The participants in the enterprise are entering a business from which they expect to draw salaries. And since salaries are ordinarily paid to officers, not directors, they may want to assure their appointment as officers.

In more than a dozen states, as in England, the law permits or directs that some or all officers be directly elected by the shareholders. ${ }^{\circ}$ In these jurisdictions a stockholders' agreement specifying who shall hold these offices is probably valid. Other state corporation laws require that officers must be designated by the directors. In these states, most courts which have passed on the subject, including the New York courts, have sustained composite agreements of all stockholders to elect certain of their number as directors, and then as directors to appoint designated persons (usually the directors) to particular offices at stated salaries. ${ }^{7}$ Agreements to pay salaries may be enforceable although the employment provision reads: " $X$ shall devote only such time to the business of the Corporation as he in his sole judgment shall deem necessary." 8 Agreements that a holder of two-thirds of the stock shall receive twice as much salary as the one-third holder are not infrequent.

Officers may ordinarily be removed without cause. ${ }^{9}$ Hence, the agree-

6. All major officers (president, secretary, treasurer): DEL. REv. CopE $\$ 2042$ (1935) ; GA. CODE ANN. \$22-1869 (Supp. 1947); Mo. Aws. Cone art. 23, §11 (Flacl: 1939); MínN. Stat. ANN. $\$ \$ 300.21,301.30$ (Supp. 1949); Neb. Rev. Stat. \$21-116 (1943); N.J. Stat. ANN. tit. 14, c. 7, §6 (Purdon 1939); N.MI. Stat. Axi. \$54215 (1941) ; N.C. Gen. Stats. $\$ \$ 55-49,55-114$ (1943) ; PA. Stat. Axw. tit. 15, \$2852-405 (Purdon Supp. 1949) ; RI. Gen. Laws Ann. c. 116, $\$ 19$ (1938) ; Wyo. Cosrp. Stat. Aziz. $\$ 44-116$ (1945). In some states some single officer may be elected by the stoclstolders, the president under VA. CODE $\$ 13-200$ (1950), and the treasurer under MLASs. LAws Asi:s. C. $156, \S 22$ (1948).

7. Where officers must be designated by the directors, there are still some states which void such an agreement as an attempt to supersede the discretion of the directors. E.g., Borland v. Sass Printing Co., 95 Colo. 53, 32 P.2d 827 (1934); Lothorp v. Godeau, 142 La. 342, 76 So. 794 (1917); Creed v. Copps, 103 Vt. 164, 152 Atl. 369 (1930).

8. Matter of Seymour Grean \& Co., 274 App. Div. 279, 82 N.Y.S.2d 787 (1st Dep't 1948). But see Goldfarb v. Dorset Products, Inc., S2 N.Y.S.2d 42, 44 (Sup. Ct. 1948). Were creditors endangered, such provisions would be unenforceable.

9. E.g., N.Y. STOCK CoRp. LAW $\$ 60$. The officer removed without cause may, however, be able to hold the corporation accountable in damages for breach of contract. 
ment must expressly provide the contrary if the parties so desire. This may be accomplished by directing that each officer shall continue in office so long as he proves "faithful, efficient and competent." ${ }^{10}$ To assure further protection for minority holders, a provision may be included that termination of employment shall be by vote of not less than a stated number of directors. Of course, such provision is of practical effect only when coupled with a prohibition against an increase in the number of directors.

A stockholders' agreement which attempts to protect an officer from removal without cause may raise interesting problems of interpretation. The directors presumably continue to have the power to dictate corporate policy, even though the agreement designates the officers, their salaries, and their period of office. Moreover, the limitation that the officer or employee may be discharged at any time for cause is implicit in every employment agreement. ${ }^{11}$ Query then if an officer refuses to conform to the policy formulated by the board, would that constitute "cause" for his removal?

\section{Determination of Corporate Policy}

Even though stockholders may validly agree to elect themselves directors and to appoint specified persons as officers, they still may not completely by-pass the board of directors by written agreement which pre-empts virtually all directoral powers. In the recent case of Long Park, Inc. v. Trenton-New Brunswick Theaters Co. ${ }^{12}$ the New York Court of Appeals held invalid, as an infringement on the board of directors' powers, a stockholders' agreement conferring on the holder of fifty per cent of the corporation's stock broad powers to manage theaters, hire and dismiss personnel, and vary entertainment policy and admission price. This type of agreement had apparently previously

10. Clark v. Dodge, 269 N.Y. 410, 199 N.E. 641 (1936). It is somewhat difficult to reconcile the implicit condition of "competence" with the frequent provisions for continuance of salary in the event of incapacity of an officer, but perhaps the latter provision will be upheld on the theory of a pension.

11. Fells v. Katz, 256 N.Y. 67,175 N.E. 516 (1931).

12. 297 N.Y. 174, 77 N.E.2d 633 (1948) ; Abbey v. Meyerson, 274 App. Div. 389, 83 N.Y.S.2d 503 (1st Dep't 1948), aff'd without opinion, 299 N.Y. 557, 85 N.E.2d 789 (1949).

The Long Park decision recalls that not so long ago it was the common practica of investment trusts to sign precisely such "management contracts" with their sponsors whereunder the latter over a long period and for a substantial fee was to handle all the investments-the only actual business of the corporation. The New York decision, therefore, was in a sense anticipated by the Investment Company Act of 1940, $\$ 15,54$ STAT. $812(1940), 15$ U.S.C. $\$ 80 \mathrm{a}-15$ (1946), which declares invalid any management contract involving investment companies unless the contract is to be renewed annually and is subject to termination on sixty days' notice. 
been valid in New York. ${ }^{13}$ Virtually the same result can still be effected to-day by the use of non-voting stock. ${ }^{14}$

Attempts to control dividend policy have been more successful. Probably no court would deny the validity of an agreement which curtails directoral discretion by forbidding the declaration of dividends under specified circumstances. A decision to the contrary would seriously affect billions of dollars of bond indentures already in existence which rely on just that limitation. The converse agreement, providing for compulsory dividends; has also been held valid; and, where sufficiently detailed and explicit, has been enforced. In Clark v. Dodge, ${ }^{15}$ for example, the New York Court of Appeals did not feel that the inclusion of a clause guarantying to the plaintiff for life onefourth of the corporation's net income "by way of salary or dividends" rendered the agreement invalid.

The general principle, however, remains that the declaration of dividends is within the discretion of the directors. Too many factors are involved for all to be explicitly "detailed" by agreement in advance. Hence, one cannot always rely upon the court's awarding specific performance of any such contractual undertaking. In any event, such a provision will have bargaining value. And when litigating a close case it may carry some weight in swaying the court.

\section{Rule by Majority Vote}

In New York agreements requiring unanimity in special situations, such as when making changes in the by-laws or in the number of directors, have long been recognized. ${ }^{10}$ But as late as 1945 , the Court of Appeals was unwilling to approve a by-law requiring that all actions taken at directors' meetings be approved by unanimous consent. Recent legislative changes, however, have validated stockholder's attempts to vary the corporate norm of majority rule. Section 9 of the New York Stock Corporation Law passed in 1948 provides that the vote of any number of directors (e.g., unanimity) may be required for the transaction of any business at a directors' meeting and, similarly, that the votes of any number of stockholders may be required for the transaction of any business at a stockholders' meeting. Moreover, Sections 35-39 passed in 1949 made significant changes with respect to the minimum percentage of stockholder vote required for

13. Lorillard v. Clyde, 86 N.Y. 384 (1881) ; Schneider v. Greater II. \& S. Circuit, Inc., 144 Misc. 534, 259 N.Y. Supp. 319 (Sup. Ct. 1932).

14. N.Y. Stock CoRp. LaW $\$ 51$.

15. 269 N.Y. 410,199 N.E. 641 (1936). But the court construed the phrase as being limited to "whatever was left for distribution after the directors had in good faith set aside whatever they deemed wise" Id. at 417,199 N.E. at 643.

16. Ripin v. United States Woven Label Co., 205 N.Y. 442,98 N.E. 855 (1912). 
structural changes. Previously structural changes had required the approval of a majority of those entitled to vote in the case of less important changes, two-thirds in the case of more important changes, and two-thirds of those adversely affected in situations prejudicial to a special class. The new sections now authorize change in each of these three situations by the percentage stated only if the certificate of incorporation does not require a larger proportion. These legislative changes now make it possible for stockholders to provide in advance for a virtual veto.

Permitting the parties to require unanimous consent is not as revolutionary as many imagine. Until comparatively recently, unanimous consent was required in many states, including New York, for charter and other organic changes and for the sale or mortgage of substantial assets. This principle was altered only by statute. Nor is the sanction of an agreement to require unanimity so very inconsistent with public policy. Veto power is frequently demanded by one who, contributing all the cash to an enterprise, receives only a minority of the stock. Although veto power in a minority is subject to abuse, so is the voting power of the majority. Full consideration should be given to both dangers.

\section{Dissolution}

Stockholders may wish to include in their agreement special provisions relating to dissolution. These provisions may be designed to give a minority which feels oppressed the right to compel dissolution. Or they may have as their purpose the prevention of dissolution where such action would prejudice a minority.

Provisions of the first type, i.e., intended to compel dissolution, are consistent with recent trends in corporate law. Until sixty years ago a minority stockholder had never been able to force a dissolution, however inequitable the behavior of the majority. Now a number of jurisdictions have statutes which empower any minority holder to apply for a court order "winding up" a company where its affairs are being conducted in a manner oppressive to some part of the membership. In addition, it is fairly well established that if a strong enough case can be proved, a court of equity has the power, even in the absence of statute, to order dissolution. ${ }^{17}$ This general equitable power has been acknowledged by statute in some states. Section 9 of the New York Stock Corporation Law, for example, permitting a requirement of unanimity for all stockholders' and all directors' actions, provides that

17. Hornstein, A Remedy for Corporate Abuse-Judicial Power to Wind Up a Corporation at the Suit of a Minority Stockholder, 40 CoL. L. Rev. 220 (1940). For a recent New York decision upholding this power, see Lennan v. Blakeley, 273 App. Div. 767, 75 N.Y.S.2d 331 (1st Dep't 1947). 
nothing in the section "shall be construed to limit the power of a court of equity to decree a dissolution in a proper case."

Although stockholders in New York cannot validly agree to limit or waive this power of a court of equity to grant dissolution, the decisions are not clear as to how far an agreement can expand the parties' power to compel dissolution. Would the courts, for example, enforce a unanimous agreement by the stockholders that the corporation should be dissolved when one of the parties dies, or enters a competing business, or on some other equally foreseeable contingency? The Court of Appeals recently affirmed without opinion an Appellate Division holding which had invalidated such an agreement because it attempted to make a "partnership" of the corporation. ${ }^{18}$ Since the effect of agreements to compel dissolution is unsettled, prompt legislative relief is necessary.

Provisions by agreement enabling the minority to compel dissolution must be sharply distinguished from equally important provisions to protect the minority from untimely dissolution. Here the interesting question arises whether the parties, by unanimous agreement before the issue of dissolution arises, may waive the absolute right which the majority or fifty per cent shareholder would otherwise have to cause dissolution. ${ }^{19}$ In New York the parties may waive their rights to compel dissolution under General Corporation Law Section 103, because the statute expressly says so. ${ }^{20}$ An agreement can probably require, moreover, that parties seeking dissolution show a real difference of opinion between the parties in the enterprise as to management matters and/or that dissolution would actually benefit all shareholders, not merely the petitioners. ${ }^{21}$

\section{Stock Purchase and Sale Agreejents}

When a closely held corporation is first formed the parties are free to select their business associates. Since the success of a small corporation may depend on the business acumen of the participants, the shareholders may wish to make certain that they will not have to deal with

18. Flanagan v. Flanagan, 273 App. Div. 918, 77 N.Y.S.2d 682 (2d Dep't 1948), offd without opinion, 298 N.Y. 787, 83 N.E.2d 473 (1948).

19. Hornstein, Voluntary Dissolution: $A N_{\text {ewi }}$ Dezelopment in Intracorporale Abusc, 51 Y ALE L.J. 64 (1941).

20. Cf. the dictum in the majority opinion of the Court of Appeals in Benintendi v. Kenton Hotel, Inc., 294 N.Y. 112, 118, 60 N.E.2d 829, 831 (1945).

21. In a recently decided case, Application of Cantelmo, 275 App. Div. 231, 85 N.Y.S.2d 604 (1st Dep't 1949), the Appellate Division held, one justice dissenting, that the owner of fifty per cent of the corporation's stock could not cause dissolution under Ges. Conp. Law $\S \S 103,117$, where there was no real difference between the parties as to management policy and where the object of the dissolution was to enable petitioners to get complete control of the business. 
possibly untalented or uncongenial associates in the future. Thus they may wish to limit the group to whom shares may be sold or they may wish to have the corporation dissolved in case some key member or members withdraw or die. In concluding agreements to this effect, the participants are varying the reputed corporate "norms" of free transferability of shares and continuous corporate existence.

\section{Restrictions on Transferability: Sale Agreements}

An absolute prohibition on transfer is against public policy and would be adjudged void, no matter how short the time specified. ${ }^{22}$ Reasonable restrictions, however, are sanctioned. The Uniform Stock Transfer Act (now in force in every one of the 48 states) impliedly recognizes the validity of some restrictions by directing that a restriction cannot be enforced unless noted on the stock certificate itself. ${ }^{23}$ A number of state statutes expressly authorize specific restrictions, ${ }^{24}$ and judicial decisions sustain still others. The questions which arise concerning restrictions on transferability are more frequently questions of interpretation than of validity.

The restriction most frequently found is a prohibition against sale of the stock to an outsider unless first offered for sale to the corporation and to the remaining stockholders. The stockholders' rights are usually, by express provision, proportioned to their respective holdings. Whether the corporation or the existing stockholders have the first chance to buy the stock is optional. Most agreements which the author has seen require that the stock first be offered to the remaining stockholders, and then to the corporation. Whatever the combination, it is always referred to as a "first option" or "first refusal." The "first option" to the corporation, or its stockholders, is sometimes extended to its directors or officers. Similar to the "first option" agreement is the frequent requirement that a stockholder who ceases to be employed by the corporation must offer to sell his stock to the corporation or its other shareholders. To avoid dispute, all agreements should clearly state whether the limitations of "first option" shall continue to bind the transferee when he wants to dispose of the stock.

The legality of these provisions may be circumscribed. A first option to the corporation will be upheld only when the corporate charter authorizes, expressly or implicitly, and when the state law does not prohibit the purchase by the corporation of its own shares.

22. But see Fisher v. Bush, 35 Hun. 641, 643 (N.Y. Sup. Ct. 1885). Query the validity, except as a "gentlemen's agreement," of the usual provision in a promoting or underwriting syndicate that none of the participants will for six months dispose of shares of stock acquired under the arrangement.

23. Uniform Stock Transfer Act §15; N.Y. Pers. Prop. Law \$ 176.

24. E.g., N.Y. STock CoRp. LAw $\$ 66$ (power of the corporation to refuse to transfer stock where stockholder is indebted to corporation). 
In some states, as in New York, the corporation may not be free to exercise the option at all times because of statutes prohibiting a corporation from purchasing its own stock except out of surplus.

Other restrictions on transferability, such as requiring approval by the directors or stockholders before a transfer may be effected, have caused courts to divide sharply. Restrictions barring transfers to certain persons, for example competitors or aliens, have likewise met judicial opposition and are, therefore, infrequently used.

\section{Withdrawal of Assets: Purchase Agreements}

Although the general subject is denominated "Purchase and Sale Agreements," it must be remembered that an agreement to sell does not necessarily imply an obligation on anyone to purchase. Preferably, the purchase obligation should be included and expressly stated. Agreements are necessary to protect not only stockholders remaining active in the corporation but also those wishing to withdraw and survivors inheriting the interest of an original venturer. As a practical matter, remaining parties are usually the only prospective purchasers of stock in a closely held corporation. Unless protected by an agreement compelling the others in the enterprise to purchase at a fair price, the stockholder who withdraws must sell for whatever is offered. And the bid is sometimes only a small fraction of the price which a sales agreement had specified as the maximum which could be asked for the stock.

There are also certain practical considerations apart from legal issues. If an agreement binds the corporation or remaining stockholders to purchase the withdrawing venturers' shares, a formula for determining selling price should always be included. Such a formula for a fair price can usually be readily agreed upon before the enterprise is started, since it is not known at that time which of the parties will be the buyer and which the seller. It is certainly easier to reach agreement upon such a formula in advance than it is when buyer and seller bicker with keen monetary interest in the result. The usual provision in an agreement is for "book value." This ordinarily will mean cost to the corporation or market value, whichever is lower. A carefully drafted instrument will expressly state whether "good-will" is to be included. If so, the agreement should specify how earnings are to be capitalized, over what period, on what percentage basis, and what allowance, if any, shall be made for loss of good-will resulting from loss of the withdrawing participant. Additional provisions in a well-drafted agreement will set forth whether and on what basis other intangible assets such as patents and tangible ones such as capital assets and inventory shall be valued; how accounts receivable are to be computed and reserves thereon determined, and whether allowance shall be made for possible corporate income tax liabilities. 
As an alternative to a formula for ascertaining value, the parties have sometimes set a specified price, usually par value, to be in effect for a number of years. The fluctuations resulting from the vagaries of business, however, make a specified price unsafe. This method of price determination may also have the effect of causing one of the parties to watch for the best moment to exercise his rights under the stockholders' agreement rather than to devote his energies to building up the mutually-owned business. Finally, arbitration or appraisal in a specified manner is a method commonly used to determine a fair price.

Tax consequences may be influential in deciding the method of arriving at the selling price. A definite formula for price fixing, if arrived at bona fide when the agreement is made, can determine the value of a stock interest for estate tax purposes. This is true even though the actual value of the stock at time of death may be many times higher than the value arrived at by use of the formula. To be effective for estate tax purposes, however, the agreement for sale at a definitely ascertainable price must have been binding during life as well as on death. ${ }^{25}$ The necessity for definiteness renders inadvisable agreements which leave the price to be fixed by arbitration. Care must be taken, of course, that the stock be not redeemed in such a way as to constitute a taxable dividend.

The efficacy of stock purchase provisions is closely related to the corporate balance sheet. In several states, as has been indicated, the corporation's agreement to purchase its own stock becomes unenforceable if there be no surplus. ${ }^{26}$ In a sense, the agreement is subject to a condition subsequent which makes it unenforceable for lack of mutuality. ${ }^{27}$ If corporate finances are close enough to the borderline so that the existence of a surplus can be a matter of accounting discretion, there is also the danger in these states that the agreement may be deliberately evaded through accounting techniques.

Provision may also be made for payment of the purchase price in cash or on time. To make sure the cash is available when wanted, life insurance policies are frequently arranged. A further provision for compulsory liquidation in the event the survivors or the corporation defaults on its obligations under the purchase part of the agreement may be desirable.

Apart from the agreement proper, the stockholder ought to be reminded that his last will and testament should direct executors to

25. Lomb v. Sugden, 82 F.2d 166 (2d Cir. 1936); Wilson v. Bowers, 57 F.2d 682 (2d Cir. 1932).

26. In some states, the purchase can be made only out of earned surplus.

27. Topken, Loring \& Schwartz v. Schwartz, 249 N.Y. 206, 163 N.E: 735 (1928). The agreement to repurchase is, however, binding upon the corporation if it docs have a surplus when the prescribed contingency occurs. 
perform any stockholders' agreement to which he may be a party at the time of death and if there is only a sale (not a purchase) agreement, that the will should empower them to retain the shares of stock as part of the estate. Where the latter provision is omitted, executors and trustees may be forced to sell the shares of stock immediately to avoid the possibility of surcharge, and there is great danger that they may have to be sacrificed. Executor discretion, however, may have an effect upon marital deductions under the new federal estate law, a danger not yet definitely evaluated but which must not be overlooked. Agreements binding stockholders to bequeath stock either to the other stockholders or to the corporation, conditioned upon the legatee paying its value or some agreed sum to the estate of the deceased, are inadvisable, in the opinion of the writer, since there is some question as to the possibility of enforcement should the bequest not be made.

\section{Arbitration}

Stockholders' agreements, like most other agreements, cannot be drafted to cover all possible contingencies. A provision for arbitration is therefore frequently included. Since 1920, when New York took the lead in empowering the courts to enforce both agreements to arbitrate and arbitration awards, experience has shown that these agreements do reduce disputes, often to the point that the formal process of arbitration is unnecessary. The differences which arise between parties reach a tension point less often when it is known that a speedy determination of any disputes will result. Valuation of stock is the one subject usually excepted from the provision for arbitration because, as noted earlier in this article, a price to be fixed by arbitration is presently inadvisable taxwise. ${ }^{23}$

The arbitration clause most frequently employed reads as follows:

"Should at any time any dispute arise between any one or more of the parties hereto with respect to his or their rights, obligations, duties and requirements under and by virtue of the provisions of this agreement, except as to the valuation of stock, said dispute, except as aforesaid, shall be referred to, and consent and approval of each of the parties hereto is expressly given to refer said dispute for determination to the American Arbitration Association, whose determination and/or decision shall be final and binding upon the parties hereto, and there shall be no appeal from said decision."

This clause or one substantially similar has been enforced by New York courts a number of times. ${ }^{29}$ When arbitration has been rejected by the

28. Chase Nat. Bank v. Mffrs. Trust Co., 265 App. Div. 406, 39 N.Y.S.2d 370 (1st Dep't 1943).

29. Martocci v. Martocci, 42 N.Y.S.2d 222 (Sup. Ct. 1943), aff'd zuilhout opinion, 
courts, the reason has been either that the contract as a whole was basically illegal and hence the arbitration clause fell with it, ${ }^{30}$ or that the controversy was not within the scope of the arbitration clause. ${ }^{31}$ For example, the courts have nullified arbitration clauses when they were included in the following types of contract adjudged illegal: agreement requiring a unanimous vote of stockholders for the election of directors; ${ }^{32}$ agreement interpreted to prevent directors from ousting one of their number for dishonesty; ${ }^{33}$ agreement for management of the corporation not by its directors, but exclusively by holders of one class of stock; ${ }^{34}$ agreement treating the corporation as a "partnership" by providing for its dissolution (distribution of its assets) on specified contingencies. ${ }^{35}$

As yet it is not certain whether an arbitration agreement could bar a stockholders' derivative suit for violations by directors or officers of fiduciary duties. Usually the New York courts have ordered arbitration ${ }^{36}$ while refusing stay of the derivative suit. ${ }^{37}$ Where an arbitration clause admittedly was "very broad and unambiguous," the court frankly ordered arbitration to proceed on the identical issues which were the subject of a contemporaneous stockholders' derivative suit. $^{38}$

New York judges take a similar position that arbitration clauses are ineffective to stay applications for dissolution under the General Corporation Law. ${ }^{39}$ Two cases explained that arbitration cannot com-

266 App. Div. 840, 43 N.Y.S.2d 516 (1st Dep't 1943), leave to appeal denied, 266 App. Div. 917, 43 N.Y.S.2d 517 ; Matter of Seymour Grean \& Co., Inc., 274 App. Div. 279, 82 N.Y.S.2d 787 (1st Dep't 1948); In re Feinberg, 118 N.Y.L.J. 20, col. 7 (Sup. Ct. July 3, 1947); Matter of Panhandle Producing \& Refining Co., Inc., 117 N.Y.L.J. 447, col. 3 (Sup. Ct. Feb. 4, 1947).

30. Berkovitz v. Arbib \& Houlberg, Inc., 230 N.Y. 261, 271-2, 130 N.玉. 288, 290 (1920).

31. Matter of Kelly, 240 N.Y. 74, 78, 147 N.E. 363, 364 (1925). For an application of this principle in a stockholders' agreement see Matter of Richman, 114 N.Y.L.J. 1878, col. 7 (Sup. Ct. Dec. 27, 1945).

32. In re Berman, 107 N.Y.L.J. 1902, col. 4 (Sup. Ct. May 5, 1942). The subjectmatter of this type of agreement would now be adjudged valid if certain formalities were observed. N.Y. Stock CoRp. LAw §9, as amended by N.Y. Laws 1948, c. 862.

33. Matter of Allied Fruit \& Extract Co., 243 App. Div. 52, 276 N.Y. Supp. 153 (1st Dep't 1934), leave to appeal denied, 266 N.Y. Iv (1934).

34. Matter of Abbey v. Meyerson, 274 App. Div. 389, 83 N.Y.S.2d 503 (1st Dep't 1948), aff'd, 299 N.Y. 557, 85 N.E.2d 789 (1949).

35. Matter of Flanagan, 271 App. Div. 1014, 68 N.Y.S.2d 248 (2d Dep't 1947). For the facts, see opinions cited in memorandum decision in Flanagan v. Flanagan, 298 N.Y. 787, 83 N.E.2d 473 (1948).

36. Lumsden v. Lumsden Bros. \& Taylor, Inc., 242 App. Div. 852, 275 N.Y. Supp. 221 (2d Dep't 1934) ; Matter of Ehrlich, 122 N.Y.L.J. 1093, col. 6 (Sup. Ct. Nov. 2, 1949).

37. Matter of Diamond, 80 N.Y.S.2d 465 (Sup. Ct. 1948), aff'd without opinion, 274 App. Div. 762, 79 N.Y.S.2d 924 (1st Dep't 1948).

38. Matter of Carl, 263 App. Div. 887, 32 N.Y.S.2d 410 (2d Dep't 1942).

39. N.Y. GEN. CoRP. LAw $\S \S 101,103$. 
pel a holder of $50 \%$ of the stock to continue in a state of constant warfare with the remaining $50 \%$ interest. ${ }^{40}$ Still other judges expressed the view that management of a corporate enterprise by arbitrators is repugnant to the concept of corporate structure. ${ }^{41}$ This view is not shared by the California legislature, which has provided that when there is a deadlock in a board of directors the court is empowered to appoint a disinterested person as provisional director to act as a director until the deadlock be broken, or until he be removed by order of the court or by vote or written consent of the holders of a majority of the voting shares. ${ }^{42}$ One New York court, it should be noted, denied an application for dissolution suggesting that the charge of mismanagement (urged as proof that the dissolution sought would be beneficial to the corporation) did appear to be a fit question for arbitration. . $^{43}$

The Ringling Bros. Barmum \& Bailey case in Delaware illustrates another use of arbitration clauses. There, two sisters had agreed to vote alike since their combined votes could elect five out of seven directors. The agreement also provided that if they failed to agree they would cast their votes as a designated third person should direct. The parties failed to agree and the issue was submitted to the arbitrator. One sister followed the arbitrator's instructions; the other did not. The court enforced the arbitration award and cancelled the vote of the disobedient sister. ${ }^{44}$ This device may not be available in New York where "agreements to agree" appear unenforceable."

The category of illegal contracts, the writer predicts, will be narroved with the passage of time, ${ }^{46}$ whereas the matter to be arbitrated will be widened as more agreements employ a standard form. Until the law with respect to arbitration is better settled some other neat questions may come up. For example, one loses his right under an arbitration agreement by proceeding to suit. ${ }^{47}$ Query then whether he

40. Matter of Cohen, 183 Misc. 1034, 52 N.Y.S.2d 671 (Sup. Ct. 1944), aff'd acrithout opinion, 269 App. Div. 663, 53 N.Y.S.2d 467 (1st Dep't 1945), levee to appeal dericd, 269 App. Div. 690, 54 N.Y.S.2d 389, and 294 N.Y. 639, 61 N.E.2d 459 (1945); In re Dome Trading Corp., 114 N.Y.L.J., 514, col. 3 (Sup. Ct. Sept. 17, 1945).

41. Miatter of Hess, 108 N.Y.L.J. 555, col. 5 (Sup. Ct. Sept. 11, 1942).

42. CAL. CORP. CODE $\$ \$ 819,4655$ (1947).

43. Application of Gail Kiddie Clothes, Inc., 56 N.Y.S.2d 117 (Sup. Ct. 1945).

44. Ringling v. Ringling Bros.-Barnum \& Bailey Combined Shows, Inc., 49 A.2d 603 (Del. Ch. 1946), madified, 53 A.2d 441 (Del. 1947). Contra: Roberts v. Whitson. 188 S.W.2d 875 (Tex. Civ. App. 1945).

45. See Benintendi v. Kenton Hotel, Inc., 294 N.Y. 112, 120, 60 N.E.2d 829, 832 (1945).

46. How will courts which still shy at the thought of directors' surrendering this type of managerial power to an arbitrator treat "union" contracts which require that wage disputes with non-executive employees be determined by arbitration?

47. Matter of Young v. Crescent Development Co., 240 N.Y. 244, 251, 14S N.E. 510, 511 (1925). 
can ask for arbitration if he has first sued and the court rules that he was bound to arbitrate?

Lawyers still perform a service in the arbitrative process. The Rules of the American Arbitration Association, the organization usually employed, expressly provide that parties may be represented by counsel. Statistics show that lawyers represent clients in eighty-two per cent of the commercial matters submitted to arbitration. The great advantage of arbitration is that it speeds up decision once a controversy has materialized.

\section{Other Drafting Problens}

A number of miscellaneous matters must be considered when an agreement is being drafted. For example, the time of the agreement is important. Some provisions are ineffective unless written into the certificate of incorporation itself. Accord upon such provisions must be reached before that document is drafted and sent to the Secretary of State. Illustrative of these provisions are the following: all the provisions permitted by the new Sections 9 and 37 of the New York Stock Corporation Law; provisions for classification of stock, an important device for assuring each stockholder the power to name a given number of directors; and certain restrictions upon the transfer of stock, such as the power of the corporation to refuse to transfer stock held by a stockholder who is indebted to the corporation. ${ }^{48}$ If not in the original certificate, an amendment thereto will be required before such objects can be effected. Even though inclusion in the certificate of incorporation may not be essential for some provisions, it still may be preferable to insert them since then shares which subsequently come into existence cannot be transferred except in accordance with the limitations thcre specified. ${ }^{49}$

Provisions invalid in a certificate of incorporation or by-law have in many states been held binding upon the parties as if they had been included in a stockholders' agreement to the same effect. In New York, however, the minority in the Benintendi ${ }^{50}$ case were unable to sway the majority into adopting this view. At the time the provisions there involved would probably have been equally unenforceable had they been in a stockholders' agreement in the first place.

A well-drafted stockholders' agreement will always direct that there be endorsed on every stock certificate an appropriate legend referring to the restrictions and to the stockholders' agreement. 'This

48. N.Y. STOCK CoRp. LAw $\$ 66$.

49. The certificate of incorporation, according to $\S 13(2)$ of the New York General Corporation Law "may contain any provision for the regulation of its business and the conduct of its affairs, and any limitation upon its powers, or upon the rights of its stockholders, or upon the powers of its directors and members, which does not exempt them from the performance of any obligation or duty imposed by law."

50. Benintendi v. Kenton Hotel, Inc., 294 N.Y. 112, 60 N.E.2d 829 (1945). 
is especially important since Section 15 of the Uniform Stock Transfer Act prohibits restrictions on transfer not stated upon the certificate. Nevertheless, when representing the purchaser of stock in a close corporation already formed, one must bear in mind that restraints upon transfer of stock may be binding, although they do not appear either on the stock certificate or in the certificate of incorporation, because the buyer had knowledge of the by-law or written agreement. Moreover, in some instances he may be charged with knowledge whether he actually had it or not.

Who should be the parties to the agreement? All the stockholders, we assume, have concurred, since anything less than unanimity of stockholders creates problems beyond the scope of this article (except as noted with respect to the choice of directors). The agreement should provide that it shall be binding upon the heirs, executors, legal representatives and assigns of the original parties. Although the corporation actually need not be a party unless it assumes obligations or may benefit under the agreement, a worldly-wise draftsman includes the rorporation.

Drafting a stockholders' agreement requires an understanding of psychology, adeptness in negotiation, skill in draftsmanship, and a broad knowledge of corporate law and its background. In working out the details of these agreements, the lawyer should remember that their purpose is to prevent later dispute and litigation. If carefully drafted, they do. ${ }^{51}$ After a stockholders' agreement has been entered into, should a dispute arise the written agreement plays an important part in the bargaining process both before and during litigation.

\section{CoNCLUSION}

We shall have stockholders' agreements as long as we have "close" corporations. Is there any reason why the courts should not sanction in these agreements provisions which deviate from the so-called corporate "norms"? Let us apply the test of public policy," fo for example, to the first "norm" allegedly required, management by the board of directors. In a recent case, a Virginia court declared that

51. The author's records indicate that of cases in New York County involving stockholders' agreements, less than ten a year on the average reach litigation. This is probably less than one per cent of the number of stockholders' agreements actually signed. Most of the cases naturally develop in the Supreme Court, but a small number show up in the Surrogate's Court, after one of the parties to the agreement has died or when the provisions of a will (by a testator who was the sole stockholder of a corporation) contain orders to trustees to elect directors who are to employ specified bencficiaries at stated salaries.

52. The alleged public policy against stockholders' agreements probably may be traced back to the 1890 s when stock-pooling agreements were among the legal forms devised to evade the antitrust laws. Cf. West v. Camden, 135 U.S. 507 (1890). 
"a private business corporation without a board of directors is an impossible concept." ${ }^{53}$ But is it so impossible? In England, whence we used to get all our concepts about corporations, until last year no board of directors at all was required in a "private company," 54 a form of organization which approximates our close corporation. And one state in this country, Iowa, does not require a board of directors. ${ }^{65}$

Nevertheless, in three-quarters of the states there is a statutory declaration like that in New York reading, "The business of a corporation shall be managed by its board of directors." ${ }^{56}$ Does this prohibit a unanimous agreement of stockholders telling the directors how they are to manage the corporation? The question almost answers itself. The New York Court of Appeals, although not always consistent, did in Clark v. Dodge render an unequivocal, four-square decision, upholding a stockholders' agreement covering this problem. The court merely noted that all stockholders were parties to the agreement and that no damage was threatened to anyone. ${ }^{57}$ And this decision was cited with approval by the majority as well as by the minority in the Benintendi case. ${ }^{58}$

New needs compel fresh formulation of corporate "norms." There is no reason why mature men should not be able to adapt the statutory form to the structure they want, so long as they do not endanger other stockholders, creditors, or the public, or violate a clearly mandatory provision of the corporation laws. In a typical close corporation the stockholders' agreement is usually the result of careful deliberation among all initial investors. In the large public-issue corporation, on the other hand, the "agreement" represented by the corporate charter is not consciously agreed to by the investors; they have no voice in its formulation, and very few ever read the certificate of incorporation. Preservation of the corporate norms may there be necessary for the protection of the public investors.

In most respects, the courts do hold stockholders' agreements binding on the parties, if fairly entered into and free from fraud. Limitations which the courts still impose will probably be gradually lessened -if not by the courts, then by the legislatures.

53. Kaplan v. Block, 183 Va. 327, 335, 31 S.E.2d 893, 896 (1944).

54. Companies Act, $1948,11 \& 12$ GEo. 6, c. 39, § 176.

55. See Iowa CODE (1946).

56. N.Y. GEN. CoRp. LAw §27.

57. Clark v. Dodge, 269 N.Y. 410, 199 N.E. 641 (1936).

58. Benintendi v. Kenton Hotel, Inc., 294 N.Y. 112, 60 N.E.2d 829 (1945). 